\title{
Agronomic performance, chromosomal stability and resistance to velvetbean caterpillar of transgenic soybean expressing cry1Ac gene
}

\author{
Milena Schenkel Homrich(1), Luciane Maria Pereira Passaglia(1), Jorge Fernando Pereira(2), \\ Paulo Fernando Bertagnolli(2), José Roberto Salvadori(2), Marcio Nicolau(2), Eliane Kaltchuk-Santos ${ }^{(1)}$, \\ Laura Bianchessi Alves ${ }^{(1)}$ and Maria Helena Bodanese-Zanettini ${ }^{(1)}$
}

\begin{abstract}
(1)Universidade Federal do Rio Grande do Sul, Departamento de Genética, Instituto de Biociências, Caixa Postal 15.053, CEP 91501-970 Porto Alegre, RS, Brazil.E-mail: milenash@terra.com.br, Ipassaglia@terra.com.br, eliane.kaltchuk@ufrgs.br, laura.alves@ufrgs.br, maria.zanettini@ufrgs.br (2)Embrapa Trigo, Caixa Postal 569, CEP 99001-970 Passo Fundo, RS, Brazil. E-mail: jorge@cnpt.embrapa.br, bertag@cnpt.embrapa.br, jrsalva@cnpt.embrapa.br, nicolau@cnpt.embrapa.br
\end{abstract}

\begin{abstract}
The objective of this work was to analyze the agronomic performance and chromosomal stability of transgenic homozygous progenies of soybean [Glycine $\max (\mathrm{L}$.) Merrill.], and to confirm the resistance of these plants against Anticarsia gemmatalis. Eleven progenies expressing crylAc, $h p t$ and gusA genes were evaluated for agronomic characteristics in relation to the nontransformed parent IAS 5 cultivar. Cytogenetical analysis was carried out on transgenic and nontransgenic plants. Two out of the 11 transgenic progenies were also evaluated, in vitro and in vivo, for resistance to $A$. gemmatalis. Two negative controls were used in resistance bioassays: a transgenic homozygous line, containing only the gusA reporter gene, and nontransgenic 'IAS 5' plants. The presence of $\operatorname{cry} 1 \mathrm{Ac}$ transgene affected neither the development nor the yield of plants. Cytogenetical analysis showed that transgenic plants presented normal karyotype. In detached-leaf bioassay, crylAc plants exhibited complete efficacy against $A$. gemmatalis, whereas negative controls were significantly damaged. Whole-plant feeding assay confirmed a very high protection of $c r y l A c$ against velvetbean caterpillar, while nontransgenic 'IAS 5' plants and homozygous gusA line exhibited 56.5 and 71.5\% defoliation, respectively. The presence of crylAc transgene doesn't affect the majority of agronomic traits (including yield) of soybean and grants high protection against $A$. gemmatalis.
\end{abstract}

Index terms: Anticarsia gemmatalis, Glycine max, plant resistance to insects, gene transfer.

\section{Performance agronômica, estabilidade cromossômica e resistência à lagarta-da-soja em soja transgênica que expressa o gene cry1Ac}

\begin{abstract}
Resumo - O objetivo deste trabalho foi analisar a performance agronômica e a estabilidade cromossômica de progênies transgênicas homozigotas de soja [Glycine max (L.) Merrill.], e confirmar a resistência dessas plantas a Anticarsia gemmatalis. Onze progênies com expressão dos genes crylAc, hpt e gusA foram avaliadas quanto às características agronômicas, em relação à cultivar parental IAS 5 não transformada. Análises citogenéticas foram realizadas em plantas transgênicas e não transgênicas. Duas das 11 progênies transgênicas também foram avaliadas quanto à resistência a $A$. gemmatalis, em bioensaios in vitro e in vivo. Dois controles negativos foram utilizados nos bioensaios: uma linha transgênica homozigota, com apenas o gene repórter gusA, e plantas de 'IAS 5' não transgênicas. A presença do transgene $c r y l A c$ não afetou nem o desenvolvimento nem a produtividade das plantas. As plantas transgênicas apresentaram cariótipo normal. No bioensaio com folhas destacadas, as plantas $c r y l A c$ exibiram completa eficácia contra A. gemmatalis, enquanto os controles negativos foram significativamente danificados. Ensaios com plantas inteiras confirmaram a elevada proteção do $c r y l A c$ contra a lagarta-da-soja, enquanto as plantas 'IAS 5' não transgênicas e a linha homozigota gusA exibiram 56.5 e $71.5 \%$ de desfolhação, respectivamente. A presença do transgene $\operatorname{cryl} l A c$ não afeta a performance agronômica da soja (incluindo a produtividade) e confere elevada proteção a A. gemmatalis.
\end{abstract}

Termos para indexação: Anticarsia gemmatalis, Glycine max, resistência de plantas a insetos, transferência de genes.

\section{Introduction}

Velvetbean caterpillar (Anticarsia gemmatalis Hübner) is a major pest of soybean, occurring mainly in growing regions of this crop in North and South Americas (Panizzi \& Corrêa-Ferreira, 1997; Macrae et al., 2005). This insect causes extremely high levels of defoliation, when infestation is heavy, and can severely damage 
axillary meristems. A single larva can consume up to $110 \mathrm{~cm}^{2}$ of soybean foliage (Walker et al., 2000). Consequently, expensive insecticide application or control measures are necessary to prevent yield losses in regions with high occurrence of A. gemmatalis (Macrae et al., 2005; Miklos et al., 2007). Chemical insecticides are commonly used for controlling infestations of velvetbean caterpillar in soybean; however, narrow application windows, the emergence of insecticide resistance, and public pressure for reducing pesticide use limit the desirability of this approach to pest management (Thomas \& Boethel, 1994). Alternative control strategies, such as biological insecticides, are available but not widely used (Luttrell et al., 1998; Moscardi, 1999), and efforts to develop elite insect-resistant soybean lines - with high yield and desirable agronomic traits, through conventional breeding of germplasms exhibiting endogenous insect resistance - have not been successful (Boethel, 1999). Recent advances in plant biotechnology, such as the use of transgenic cultivars to better exploit host plant resistance, have provided new approaches for the management of insect pests. One of the most promising of these approaches is the development of cultivars that express one of the delta-endotoxin genes from Bacillus thuringiensis (Bt) subsp. kurstaki (Roush, 1997). B. thuringiensis has long been used for controlling insect pests as a biological insecticide. The activity of delta-endotoxin from $B$. thuringiensis in controlling the larvae of A. gemmatalis has been described (Stewart Junior et al., 1996; Walker et al., 2000; Macrae et al., 2005; Miklos et al., 2007).

In a previous study, Homrich et al. (2008) developed an 'IAS 5' transgenic line containing an intact copy of a truncated synthetic crylAc gene from $B$. thuringiensis. A preliminary in vitro insect feeding assay indicated that transgenic plants were highly toxic to A. gemmatalis larvae.

The introduction of a transgene into a recipient genome is a complex event depending on the transgene itself and the host genome (Yin et al., 2004). Agronomic traits of field crops may become adversely affected upon their transformation with foreign genes. According to Filipecki \& Malepszy (2006), the unintended effects in transgenic plants can be divided into three main groups: first, pleiotropic effects of integrated DNA on the host plant genome; second, the influence of the integration site and transgene architecture on transgene expression level and stability; and third, the effect of various stresses related to tissue handling, regeneration and clonal propagation.

Genetic alterations and chromosomal abnormalities of regenerated plants, based on tissue culture process (somaclonal variation), have been described for many plant species, including soybean (Stephens et al, 1991; Singh et al., 1998; Jain, 2001). Many plant characters can be altered, including plant height, yield, number of flowers per plant, grain quality, and resistance to diseases, insects, pests, cold, drought and salt (Jain, 2001). The change in chromosome number is commonly associated with reduced fertility and with altered genetic ratios in the progeny of self-pollinated plants (Singh et al., 1998). Thus, agronomic performance evaluation of transformed plants is necessary to evaluate if nontransgenic parent cultivar traits, including desirable yield components, have been retained along the tissue culture, transformation and regeneration processes. It is also important to ascertain if the obtained transgenic plants present normal karyotype $(2 \mathrm{n}=40)$.

The objective of this work was to characterize 11 homozygous crylAc progenies, by comparing agronomic characteristics and yields; to establish the chromosomal stability in relation to the nontransformed parent IAS 5 cultivar; and to confirm the resistance of these plants against $A$. gemmatalis larvae.

\section{Materials and Methods}

The transgenic progenies of the cultivar IAS 5, analyzed in this study, were developed by Homrich et al. (2008) and carry the synthetic crylAc, hpt and gusA genes. The crylAc gene is truncated in the $\mathrm{C}$ terminus region and harbors the intact $\mathrm{N}$ terminus region of the native gene (Sardana et al., 1996). B. thuringiensis toxins produced in transgenic plants have often been expressed as protein-truncated at the $\mathrm{C}$ terminus, because this has resulted in higher expression levels (Vaeck et al., 1987). In terms of codon usage, the crylAc gene was designed for expression in dicots and has a $\mathrm{G}+\mathrm{C}$ content of $47.7 \%$. The overall modifications have resulted in higher expression levels of Cry1 Ac in transgenic plants (Sardana et al., 1996).

A transgenic homozygous line harboring only gusA reporter gene, obtained in the previous work (Homrich et al., 2008), was used as a negative control in the bioassays. This gusA line was likely derived by interchromosomal recombination from transformants, 
which contained crylAc, hpt and gusA genes integrated at a single locus.

The progenies included in the present study were obtained from self-pollination of eleven $\mathrm{T}_{3}$ homozygous transgenic plants. The $\mathrm{T}_{3}$ homozygous plants resulted from the same transformation event (Homrich et al., 2008). The progenies identified by the numbers 44,46 , 162, 169, 438, 497, 507, 520, 551, 937, 1274 were evaluated for their agronomic performance. A greenhouse experiment was conducted at Embrapa Trigo, in Passo Fundo, Rio Grande do Sul State, Brazil, to compare the transgenic progenies with nontransgenic 'IAS 5' regarding: date of emergence, initial development, seedling hypocotyl color, flower color, pubescence color, growth habit, plant height, number of nodes, flowering date, maturity date, seed tegument color, seed hilum color, 100 -seed weight, number of seeds and total grain yield. Initial development was scored 15 days after planting using a scale of 1 (poorly developed first trifoliolate leaf) to 5 (completely developed first trifoliolate leaf).

Seeds were individually planted in $30-\mathrm{cm}$ plastic pots containing $8 \mathrm{~kg}$ of soil fertilized with an equivalent of $500 \mathrm{~kg} \mathrm{ha}^{-1}$ of $0-25-25$ (N-P-K) and $6 \mathrm{Mg} \mathrm{ha}^{-1}$ of lime, in accordance with soil analysis. Seeds were sown in December 2006 and harvested in April 2007, in a greenhouse, under natural light at $25 \pm 5^{\circ} \mathrm{C}$, relative humidity of about $50 \pm 10 \%$, and photoperiod varying from 14 hours in December to 12 hours in April. Water was daily applied to soil, using a dripping system. Pots were arranged in randomized complete blocks design. Plants grew until physiological seed maturity. Data were recorded from six plants per progenie and six nontransgenic 'IAS 5' plants.

ANOVA was performed, using the GLM procedure of SAS (SAS Institute, 2004). When the assumptions for this test were not met, variable transformations were selected according to Box \& Cox (1964). Transformations were performed on initial development $\left(\mathrm{x}^{2}\right)$, flowering date $\left(1 / \mathrm{x}^{4}\right)$, plant height (natural $\log$ ) and number of nodes ( $1 / \mathrm{x})$. Multiple comparisons were made using Tukey's HSD test, at $5 \%$ probability.

For the cytogenetical analysis, chromosome numbers (mitotic pro-metaphase to metaphase chromosomes) were determined in five transgenic progenies $(44,169$, 438,937 and 1274) and in nontransgenic control plants, with three repetitions (plants) per genotype. Ten cells were analyzed per plant. A total of 180 cells from root tips of five transgenic progenies and nontransgenic control plants were analyzed. Root tips with $1 \mathrm{~cm}$ in length were removed from seedlings of the transgenic plants and the nontransgenic control plants. Root-tip squash and chromosome counts were carried out according to Bodanese-Zanettini et al. (1996). The root tips were pretreated with a saturated solution of paradichlorobenzene for $18-20$ hours at $4^{\circ} \mathrm{C}$, fixed in 3:1 ethanol:acetic acid for 12-24 hours, and stored in $70 \%$ ethanol at $18^{\circ} \mathrm{C}$ until required. Tips were, then, hydrolyzed in $1 \mathrm{~N} \mathrm{HCl}$ at $60^{\circ} \mathrm{C}$ for $8 \mathrm{~min}$ and subsequently stained with leuco-basic fuchsin. Chromosome counts were made on well-spread metaphases from intact cells, directly on the microscope.

For the insect bioassay, two homozygous crylAc, hpt and gusA transgenic progenies $(162 ; 438)$ were evaluated through in vitro and in vivo assays for resistance to A. gemmatalis. A homozygous gusA line (732) and nontransgenic 'IAS 5' plants were used as negative controls. Velvetbean caterpillar eggs were provided by Embrapa Soja (Londrina, PR, Brazil). In vitro and in vivo assays were conducted at Embrapa Trigo (Passo Fundo, Rio Grande do Sul State, Brazil).

In order to evaluate the in vitro insecticidal activity of transgenic and control plants towards A. gemmatalis larvae, leaflets from trifoliolate leaves were placed in 100x20 mm Petri dishes, containing a piece of moistened filter paper, and were incubated for 72 hours at $25^{\circ} \mathrm{C}$ with 12 hours photoperiod. The leaf tissue was kept as uniform as possible (about $200 \mathrm{mg}$ ) from one dish to another, with leaves being replaced as necessary. Leaf samples were infested with 20 second-instar larvae of A. gemmatalis per plate. After 24 hours, the percentage of foliage consumption was estimated. Leaf consumption percentages were converted to scores as follow: 1 (very low consumption), 2 (less than 50\%), 3 (around 50\%) and 4 (almost 100\% consumption). The number of alive and dead larvae was determined 24, 48 and 72 hours after infestation. At the end of the experiment, the surviving larvae had their development and weight evaluated.

The whole-plant feeding assay was carried out in a greenhouse. The transgenic and controls seeds were planted in $30-\mathrm{cm}$ diameter plastic pots filled with soil fertilized [500 kg ha-1 of 0-25-25 (N-P-K) and $6 \mathrm{Mg} \mathrm{ha}^{-1}$ lime] and were maintained under natural light at $25 \pm 5^{\circ} \mathrm{C}$. A randomized complete block design was used with six repetitions (plants) per genotype. Each plant was infested with 50 second-instar larvae, when plants were in the V3 to V4 stage of development. Resistance was evaluated 
through visual estimates of defoliation percentages and the insect survivorship 7 and 14 days after infestation. Percent defoliation refers to the percentage of leaves with consumed area higher than $50 \%$.

\section{Results and Discussion}

No variation was observed within transgenic progenies and among transgenic progenies and the nontransgenic 'IAS 5' control plants, for the following agronomic traits: date of emergence (6-7 days); seedling hypocotyl color (light green); flower color (white); pubescence color (grey); growth habit (determinate); maturity (155 days); seed tegument color (yellow); seed hilum color (light brown). These traits are in accordance with the 'IAS 5' description.

Significant differences were observed for initial development, flowering date, plant height, number of nodes, number of seeds, 100 -seed weight, and total grain weight (Table 1). Ten days after planting, the nontransgenic 'IAS 5' control was at a more advanced development stage $($ score $=4.67$ ) than those of the transgenic plants. Only two transgenic progenies (937, 520) showed a late flowering, while the other progenies did not differ from nontransgenic 'IAS 5' control. Likewise, the number of nodes and plant height at maturity of most of the transgenic plants did not differ from the control.

Concerning the yield evaluation, five transgenic progenies $(169,438,497,520,1274)$ had a significant lower 100-seed weight, while the other progenies did not differ from the control. However, for the number of seeds and total grain yield, no significant differences were detected among the transgenic progenies and the control. Thus, yield components measured for the majority of transgenic progenies, tested in the present study, were comparable to the parental cultivar IAS 5, suggesting retention of desirable market traits by these plant lines. Taking into account the majority of analyzed traits, the presence of crylAc transgene did not affect the yield and the agronomic performance of the transgenic plants. Stewart Junior et al. (1996) reported similar results for soybean transgenic lines expressing a synthetic crylAc gene. According to these authors, plants morphologically normal and fertile were produced in the greenhouse for four generations. Similarly, Miklos et al. (2007) showed no significant differences in agronomic performance (emergence, flowering, plant height, lodging, maturity and yield) of transgenic soybean plants containing a highly expressed crylA gene. Maqbool \& Christou (1999) also observed that in most rice transgenic plants, the expression of crylAc, cry2A, gna (snowdrop lectin) and $h p t$ genes did not affect the overall morphological phenotype. However, the authors verified that plants with very high protein levels occasionally showed developmental abnormalities, including sterility and stunted growth.

Cytological examination of cells showed that transgenic plants and controls presented normal karyotype $(2 n=40)$ with no apparent chromosomal abnormalities. Singh et al. (1998) provided extensive cytological information on transformed soybean produced by bombardment of embryogenic suspension cultures. Various chromosomal aberrations, such as deletions,

Table 1. Agronomic performance of $\mathrm{T}_{4}$ transgenic plants for initial development (ID), flowering date (FD), plant height (PH), number of nodes (NN), number of seeds (NS), 100-seed weight (100-SW) and total grain weight (TGW) ${ }^{(1)}$.

\begin{tabular}{llllllll}
\hline Lines & ID & FD & PH & NN & NS & $100-$ SW & TGW \\
\hline 44 & $2.33 \mathrm{c}$ & $51.17 \mathrm{abc}$ & $56.83 \mathrm{~b}$ & $12.33 \mathrm{~cd}$ & $120.83 \mathrm{~b}$ & $16.67 \mathrm{ab}$ & $20.10 \mathrm{ab}$ \\
46 & $2.67 \mathrm{c}$ & $47.17 \mathrm{c}$ & $53.67 \mathrm{~b}$ & $12.33 \mathrm{~cd}$ & $125.50 \mathrm{~b}$ & $15.93 \mathrm{abc}$ & $20.01 \mathrm{~b}$ \\
162 & $3.17 \mathrm{bc}$ & $47.17 \mathrm{c}$ & $74.33 \mathrm{ab}$ & $13.33 \mathrm{abcd}$ & $204.33 \mathrm{a}$ & $16.22 \mathrm{ab}$ & $32.00 \mathrm{a}$ \\
169 & $3.17 \mathrm{bc}$ & $47.00 \mathrm{c}$ & $56.33 \mathrm{~b}$ & $11.83 \mathrm{~d}$ & $145.00 \mathrm{ab}$ & $14.92 \mathrm{bc}$ & $21.23 \mathrm{ab}$ \\
438 & $3.17 \mathrm{bc}$ & $56.17 \mathrm{abc}$ & $71.83 \mathrm{ab}$ & $12.83 \mathrm{abcd}$ & $141.83 \mathrm{ab}$ & $15.24 \mathrm{bc}$ & $21.44 \mathrm{ab}$ \\
497 & $3.00 \mathrm{bc}$ & $49.00 \mathrm{bc}$ & $67.67 \mathrm{ab}$ & $12.67 \mathrm{bcd}$ & $132.33 \mathrm{ab}$ & $15.59 \mathrm{bc}$ & $20.28 \mathrm{ab}$ \\
507 & $3.17 \mathrm{bc}$ & $53.00 \mathrm{abc}$ & $97.67 \mathrm{a}$ & $15.33 \mathrm{abc}$ & $164.33 \mathrm{ab}$ & $16.65 \mathrm{ab}$ & $26.69 \mathrm{ab}$ \\
520 & $3.00 \mathrm{bc}$ & $58.50 \mathrm{a}$ & $105.50 \mathrm{a}$ & $15.33 \mathrm{ab}$ & $140.50 \mathrm{ab}$ & $14.01 \mathrm{c}$ & $19.29 \mathrm{~b}$ \\
551 & $3.50 \mathrm{bc}$ & $57.00 \mathrm{ab}$ & $107.00 \mathrm{a}$ & $15.83 \mathrm{a}$ & $137.33 \mathrm{ab}$ & $16.20 \mathrm{ab}$ & $21.74 \mathrm{ab}$ \\
937 & $3.33 \mathrm{bc}$ & $59.33 \mathrm{a}$ & $103.67 \mathrm{a}$ & $15.00 \mathrm{abc}$ & $153.17 \mathrm{ab}$ & $16.21 \mathrm{ab}$ & $22.96 \mathrm{ab}$ \\
1274 & $3.83 \mathrm{~b}$ & $50.83 \mathrm{abc}$ & $68.00 \mathrm{ab}$ & $12.83 \mathrm{bcd}$ & $124.67 \mathrm{~b}$ & $15.56 \mathrm{bc}$ & $19.05 \mathrm{~b}$ \\
$\mathrm{NT}^{(2)}$ & $4.67 \mathrm{a}$ & $49.17 \mathrm{bc}$ & $96.00 \mathrm{a}$ & $15.33 \mathrm{ab}$ & $162.33 \mathrm{ab}$ & $17.66 \mathrm{a}$ & $29.05 \mathrm{ab}$ \\
\hline
\end{tabular}

${ }^{(1)}$ Means followed by the same letters, in the columns, do not differ from each other by Tukey's HSD test, at 5\% probability. ${ }^{(2)}$ Nontransgenic 'IAS 5 ' control. 
duplications, aneuploidy and tetraploidy, were described. That study showed that soybean genotypes differ in their susceptibility to chromosomal instability induced by tissue culture. Therefore, chromosome analysis can help eliminate chromosomally abnormal plants from transformation experiments.

For the in vitro detached-leaf feeding assay, isolated leaves were infested with neonate larvae of A. gemmatalis. After 24 hours, leaves from the homozygous gusA line and from the nontransgenic plants were completely defoliated (Figure 1). In contrast, consumption was significantly reduced in homozygous crylAc transgenic leaves (Table 2 and Figure 1). Larvae fed on $c r y l A c$ transgenic leaves showed browning and

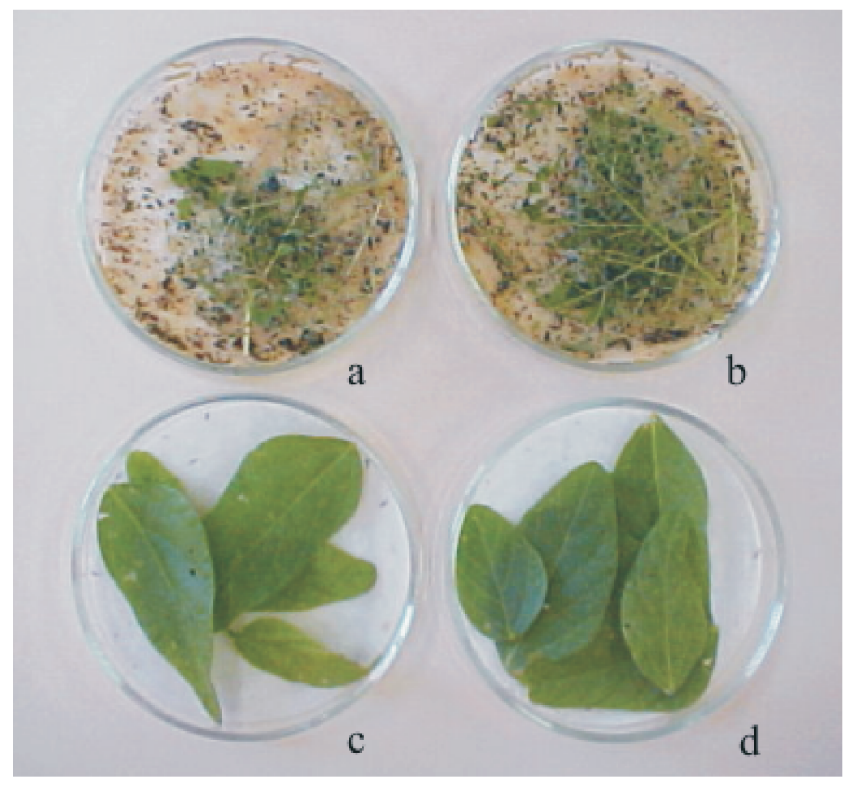

Figure 1. Detached-leaf feeding assay. Defoliation of nontransgenic controls 'IAS 5' (a) and gusA isoline (b), and crylAc transgenic 162 isoline (c) and 438 isoline (d) leaves, 24 hours after infestation with Anticarsia gemmatalis larvae. severe growth retardation, in comparison to larvae fed on control leaves. Considering the larval weight on nontransgenic leaves as $100 \%$, the larvae reared on cry $1 A c$ leaves had greatly reduced weight (64 and 66\% for 162 e 438 progenies, respectively). The fate of the larvae was monitored for two more days. Seventy-two hours after infestation, larvae reared on crylAc leaves exhibited $100 \%$ mortality, compared with $1.65 \%$ larvae fed on leaves from both nontransgenic and gusA plants.

Insect damage in whole-plant feeding assay was similar to the detached-leaf feeding experiments, as control plants suffered a much greater amount of leaf damage than transgenic plants (Table 2 and Figure 2). The percent defoliation of the homozygous gusA line (732) and nontransgenic 'IAS 5' plants, fourteen days after the infestation, was, in average, 56.5 and $71.5 \%$, respectively. However, almost no damage was observed on crylAc transgenic progenies $(162,438)$.

Although experimental lines have been developed, $B t$ soybean cultivars have not yet been commercialized. A transgenic line of soybean Jack cultivar, expressing a synthetic crylAc gene, caused complete A. gemmatalis larval mortality, in laboratory bioassays (Stewart Junior et al., 1996) and in artificially infested field cages (Walker et al., 2000). More recently, transgenic lines of soybean (A5547), expressing a synthetic crylA gene, were evaluated for the resistance against several lepidopteran pests in screenhouse and in conventional field trials, in which $B t$ lines exhibited virtually complete efficacy against all pests tested (Macrae et al., 2005). Moreover, Miklos et al. (2007) reported the generation of three transgenic soybean lines via Agrobacterium-mediated gene transfer of a crylA gene (tic 107), which exhibited a high degree of resistance against lepidopteran pests (Pseudoplusia includens, Helicoverpa zea, and A. gemmatalis) in leaf disc and whole-leaf bioassays.

Table 2. Feeding assay of neonate larvae of Anticarsia gemmatalis on detached leaves and on whole plants ${ }^{(1)}$.

\begin{tabular}{|c|c|c|c|c|c|c|c|}
\hline \multirow[t]{2}{*}{ Genotype } & \multirow{2}{*}{$\frac{\text { Leaf consumption }}{24 \mathrm{~h}}$} & \multirow{2}{*}{$\frac{\text { Larval weight }(\mathrm{mg})}{24 \mathrm{~h}}$} & \multicolumn{3}{|c|}{ Mortality (\%) } & \multicolumn{2}{|c|}{ Defoliation (\%) } \\
\hline & & & $24 \mathrm{~h}$ & $48 \mathrm{~h}$ & $72 \mathrm{~h}$ & $\begin{array}{l}\text { Seven days after } \\
\text { infestation (mean) }\end{array}$ & $\begin{array}{c}\text { Fourteen days after } \\
\text { infestation (mean) }\end{array}$ \\
\hline 162 & 1.0 & 0.40 & 90.8 & 98.3 & 100.0 & 0.0 & 0.0 \\
\hline 438 & 1.0 & 0.39 & 85.0 & 95.0 & 100.0 & 0.0 & 0.0 \\
\hline 732 & 3.7 & 1.56 & 0.8 & 1.6 & 1.6 & 60.0 & 71.5 \\
\hline $\mathrm{NT}^{(2)}$ & 3.8 & 1.12 & 1.6 & 1.6 & 1.6 & 37.5 & 56.5 \\
\hline
\end{tabular}

(1)Feeding assay on detached leaves: twenty larvae were applied to detached leaves; leaf consumption scores: 1 (very low consumption), 2 (less than 50\%), 3 (around 50\%) and 4 (almost 100\% consumption); whole-plant feeding assay: each plant was infested with 50 velvetbean caterpillar larvae; the percent defoliation refers to the percentage of leaves with consumed area higher than 50\%. (2)Nontransgenic 'IAS 5 ' plants. 

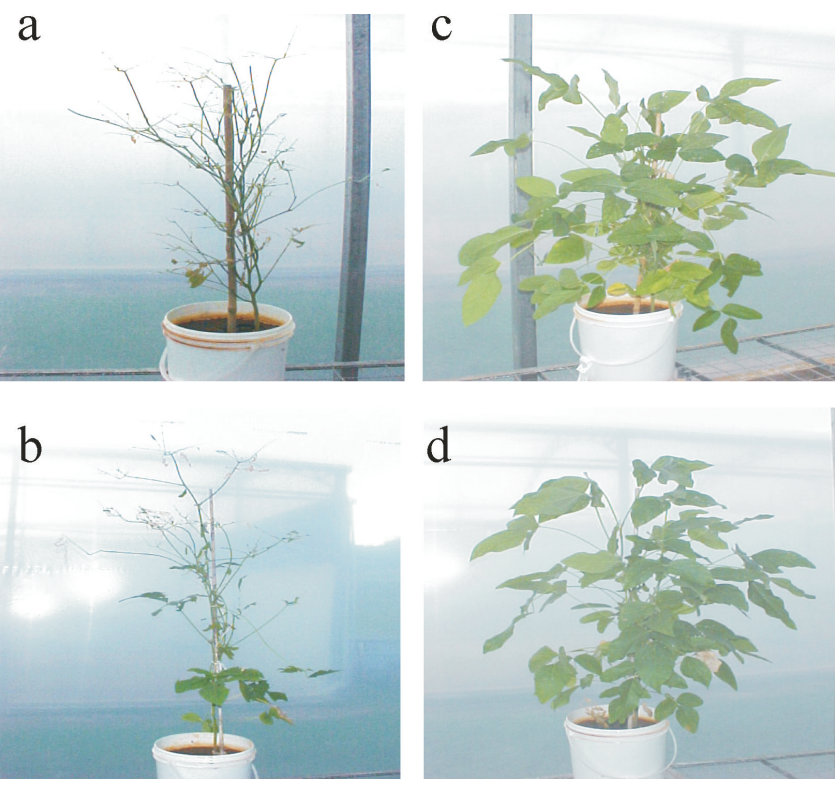

Figure 2. Whole-plant feeding assay. Defoliation of nontransgenic controls 'IAS 5' (a) and gusA isoline (b), and crylAc transgenic 162 isoline (c) and 438 isoline (d) leaves, 14 days after infestation with Anticarsia gemmatalis larvae.

The results obtained in the present study showed that the high level of resistance against velvetbean caterpillar is similar or even higher than that reported by Miklos et al. (2007).

\section{Conclusions}

1. The presence of the crylAc transgene doesn't affect the development of the majority of transgenic progenies tested and yield of soybean plants.

2. Transgenic plants present normal karyotype $(2 \mathrm{n}=40)$ with no apparent chromosomal abnormalities.

3. Progenies with crylAc are resistant to Anticarsia gemmatalis.

\section{Acknowledgements}

To Dr. Flávio Moscardi, of Embrapa Soja, for providing Anticarsia gemmatalis eggs; to Conselho Nacional de Desenvolvimento Científico e Tecnológico, Fundação de Amparo à Pesquisa do Rio Grande do Sul, and Pró-Reitoria de Pesquisa e Pósgraduação da Universidade Federal do Rio Grande do Sul, for financial support.

\section{References}

BODANESE-ZANETTINI, M.H.; LAUXEN, M.S.; RICHTER, S.N.C.; CAVALLI-MOLINA, S.; LANGE, C.E.; WANG, P.J.; HU, C.Y. Wide hybridization between Brazilian soybean cultivars and wild perennial relatives. Theoretical and Applied Genetics, v.93, p.703-709, 1996.

BOETHEL, D.J. Assessment of soybean germplasm for multiple insect resistance. In: CLEMENT, S.L.; QUISENBERRY, S.S. (Ed.). Global plant genetic resources for insect-resistant crops. Boca Raton: CRC Press, 1999. p.101-129.

BOX, G.E.P.; COX, D.R. An analysis of transformations (with discussion). Journal of the Royal Statistical Society B, v.26, p.211-252, 1964.

FILIPECKI, M.; MALEPSZY, S. Unintended consequences of plant transformation: a molecular insight. Journal of Applied Genetics, v.47, p.277-286, 2006.

HOMRICH, M.S.; PASSAGLIA, L.M.P.; PEREIRA, J.F.; BERTAGNOLLI, P.F.; PASQUALI, G.; ZAIDI, M.A.; ALTOSAAR, I.; BODANESE-ZANETTINI, M.H. Resistance to Anticarsia gemmatalis Hübner (Lepidoptera, Noctuidae) in transgenic soybean (Glycine max (L.) Merrill., Fabales, Fabaceae) cultivar IAS5 expressing a modified Cry $1 \mathrm{Ac}$ endotoxin. Genetics and Molecular Biology, v.31, p.522-531, 2008.

JAIN, S.M. Tissue culture-derived variation in crop improvement. Euphytica, v.118, p.153-166, 2001.

LUTTRELL, R.G.; ALI, A.; YOUNG, S.Y.; KNIGHTEN, K. Relative activity of commercial formulations of Bacillus thuringiensis against selected noctuid larvae (Lepidoptera:Noctuidae). Journal of Entomological Science, v.33, p.365-377, 1998.

MACRAE, T.C.; BAUR, M.E.; BOETHEL, D.J.; FITZPATRICK, B.J.; GAO, A.G.; GAMUNDI, J.C.; HARRISON, L.A.; KABUYE, V.T.; McPHERSON, R.M.; MIKLOS, J.A.; PARADISE, M.S.; TOEDEBUSCH, A.S.; VIEGAS, A. Laboratory and field evaluations of transgenic soybean exhibiting high-dose expression of a synthetic Bacillus thuringiensis cry $1 A$ gene for control of Lepidoptera. Journal of Economic Entomology, v.98, p.577-587, 2005.

MAQBOOL, S.B.; CHRISTOU, P. Multiple traits of agronomic importance in transgenic indica rice plants: analysis of transgene integration patterns, expression levels and stability. Molecular Breeding, v.5, p.471-480, 1999.

MIKLOS, J.A.; ALIBHAI, M.F.; BLEDIG, S.A.; CONNORWARD, D.C.; GAO, A.G.; HOLMES, B.A.; KOLACZ, K.H.; KABUYE, V.T.; MACRAE, T.C.; PARADISE, M.S.; TOEDEBUSCH, A.S.; HARRISON, L.A. Characterization of soybean exhibiting high expression of a synthetic Bacillus thuringiensis crylA transgene that confers a high degree of resistance to Lepidopteran pests. Crop Science, v.47, p.148-157, 2007.

MOSCARDI, F. Assessment of the application of baculoviruses for control of Lepidoptera. Annual Review of Entomology, v.44, p.257-289, 1999.

PANIZZI, A.R.; CORRÊA-FERREIRA, B.S. Dynamics in the insect fauna adaptation to soybean in the tropics. Trends in Entomology, v.1, p.71-88, 1997. 
ROUSH, R.T. $B t$ transgenic crops: just another pretty insecticide or a chance for a new start in resistance management? Pesticide Science, v.51, p.328-334, 1997.

SARDANA, R.; DUKIANDJIEV, S.; GIBAND, M.; CHENG, X.; COWAN, K.; SAUDER, C.; ALTOSAAR, I. Construction and rapid testing of synthetic and modified toxin gene sequences CryIA (b \& c) by expression in maize endosperm culture. Plant Cell Reports, v.15, p.677-681, 1996.

SAS INSTITUTE. JMP introductory guide: version 5.1.1. Cary: SAS Institute, 2004.

SINGH, R.J.; KLEIN, T.M.; MAUVAIS, C.J.; KNOWLTON, S.; HYMOWITZ, T.; KOSTOW, C.M. Cytological characterization of transgenic soybean. Theoretical and Applied Genetics, v.96, p.319-324, 1998.

STEPHENS, P.A.; NICKELL, C.D.; WIDHOLM, J.M. Agronomic evaluation of tissue-culture-derived soybean plants. Theoretical and Applied Genetics, v.82, p.633-635, 1991.

STEWART JÚNIOR, C.N.; ADANG, M.J.; ALL, J.N.; BOERMA, H.R.; CARDINEAU, G.; TUCKER, D.; PARROTT, W.A. Genetic transformation, recovery, and characterization of fertile soybean transgenic for a synthetic Bacillus thuringiensis crylAc gene. Plant Physiology, v.112, p.121-129, 1996.

THOMAS, J.D.; BOETHEL, D.J. Synergism of insecticides in tests with resistant soybean looper larvae (Lepidoptera: Noctuidae) in the laboratory and field. Journal of Economic Entomology, v.87, p.1416-1422, 1994.

VAECK, M.; REYNAERTS, A.; HÖFTE, H.; JANSENS, S.; BEUCKELEER, M.D.; DEAN, C.; ZABEAU, M.; MONTAGU, M.V.; LEEMANS, J. Transgenic plants protected from insect attack. Nature, v.328, p.33-37, 1987.

WALKER, D.R.; ALL, J.N.; McPHERSON, R.M.; BOERMA, H.R.; PARROTT, W.A. Field evaluation of soybean engineered with a synthetic $\operatorname{cry} 1 A c$ transgene for resistance to corn earworm, soybean looper, velvetbean caterpillar (Lepidoptera: Noctuidae), and lesser cornstalk borer (Lepidoptera: Pyralidae). Journal of Economic Entomology, v.93, p.613-622, 2000.

YIN, Z.; PLADER, W.E.; MALEPSZY, S. Transgene inheritance in plants. Journal of Applied Genetics, v.45, p.127-144, 2004.

Received on February 28, 2008 and accepted on June 13, 2008 